\title{
Congenital Bleeding Disorder
}

National Cancer Institute

\section{Source}

National Cancer Institute. Congenital Bleeding Disorder. NCI Thesaurus. Code C103172.

A bleeding disorder that is diagnosed during childhood, with the presenting symptom of excessive bleeding. 